\title{
City Greens, Post Amphan: A Gender-Education-Profession Based Qualitative Survey
}

\author{
Rakheebrita Biswas ${ }^{1}$, Supatra Sen ${ }^{2}$ \\ Assistant Professor [W.B.E.S.], Dept. of Botany (B.Ed.), Institute of Education (P.G.) for Women, Chandernagore, \\ Hooghly, West Bengal, India \\ Associate Professor, Dept. of Botany, Asutosh College, Kolkata, India
}

Correspondence E-mail : rbrakhee@gmail.com; supatrasen@gmail.com

\begin{abstract}
Kolkata has lost a substantial portion of its green cover due to the tropical super-cyclone Amphan which struck on $20^{\text {th }}$ May 2020 . The green casualty consisted mostly of old trees fully grown with a large canopy. Post Amphan it was found necessary to conduct a qualitative survey about the citizen's stand (surveyed on the basis of gender, education and profession) on the havoc caused by Amphan, their reasons for the disastrous loss of greenery and their stand on future greening of their city.

The survey revealed women consider community green spaces as a definite contributing feature in urban greening. Community green spaces chosen by women is a positive feature, for encouraging such spaces would promote urban greening. This indicates women being sensitive to environmental challenges and crises. As the future greening programme most participants opted for the right species to be planted on the roadsides. This also conclusively proves that urban green planning is to be executed with utmost care, background knowledge and firsthand experience. The principles of 'Right place, Right tree,' 'Safety First', landscape architecture besides plant traits, characters and requirements must serve as strong guiding factors.
\end{abstract}

Keywords: urban greening, profession, sustainable urbanization, super cyclone, biodiversity restoration, Amphan

\section{Introduction}

Amphan, a tropical super cyclone ravaged coastal Bengal, Orissa and parts of Bangladesh on 20th May 2020. North and South 24 Parganas and East Midnapore districts of West Bengal were the worst affected with lakhs rendered homeless and shelterless, huge agricultural and crop loss, thousands of trees damaged, destroyed and uprooted and other accompanying damages and losses much beyond immediate comprehension and repair. Kolkata has lost a substantial portion of its green cover due to this cyclone. The green casualty consisted mostly of old trees fully grown with a large canopy (Sen, 2020a). With over 15000 trees lost or damaged out of approximately five lakhs in Kolkata alone, the task to urban-green restoration remains greatly challenging.

\section{OBJECTIVES}

Post Amphan it was found necessary to conduct a qualitative survey about the citizen's stand [in relation to their gender, profession and academic qualification] on the havoc caused by Amphan, their reasons for the 
Int J Adv Life Sci Res. Volume 3(4)37-50

disastrous loss of greenery and their stand on future greening of their city.

a. To see the overall awareness of the people about the location of plants in their locality, whether the plants are in their own private terrace/balcony/roof-top or garden or in public community park/playground/garden or at the roadside/avenue.

b. To find out post- Amphan about the nature of damage to the plants, whether they were completely uprooted or with broken branches or bent or remained totally unaffected.

c. To find out the precise location of the damaged or uprooted trees, whether they were situated in the roadside, cemented around roots or roadside, uncemented around roots or in community parks or in own garden.

d. To find out the most probable cause(s) of damaged/uprooted trees (mostly due to overgrown canopy or shallow roots or weakly wooded stems \& brittle branches or being diseased and infected).

e. To observe the reason for tree damage from the perspectives of lack of space, overcrowded with wires, cables etc. or due to unscientific pruning/no pruning or ignorance of 'Right place, right tree' norm or even wrong species selection.

f. To assess the future urban greening plan in terms of tree plantation through the adaptation of various ways and means such as either planting trees only in the community green spaces or on roadsides or planting of right species only or limiting plants in one's personal garden only or just keeping it unchanged as it has been all this while.

The study could give us an insight whether gender, profession and academic qualification of selected participants determined their environmental awareness, perspective and concern.

\section{Material and Method}

Variables:

\section{Dependent Variable:}

- Awareness related to City Greens

\section{Independent Variable:}

- Gender (male and female)

- Profession (Employed/ Student/ Seeking Employment / Homemaker)

- Academic Qualification/Education (Ph.D./P.G./P.G.-M.Ed./B.Ed./Graduate)

\section{Delimitations:}

The data was limited to 50 people/participants [both male and female] only of Kolkata and adjoining areas of West Bengal.

\section{Tools:}

An information schedule cum questionnaire was formulated by the researchers for collecting data.

\section{Methodology:}

The study was designed on a survey based descriptive research methodology. The questionnaire was administered on the selected sample to collect data and the data was qualitatively analyzed (by percentage analysis) to describe further.

\section{Sample:}

The sample comprised of 50 participants out of which 39 were female and 11 were male, living in different parts of Kolkata and adjoining areas (so that more or less Amphan would have had similar impact) between 25-40 years of age (Figure 1).

Figure 1: Gender- wise Distribution of Sample

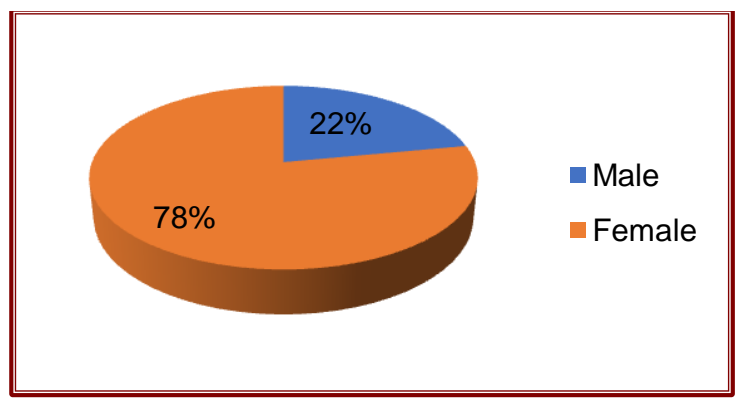

Figure 2: Profession- wise Distribution of Sample

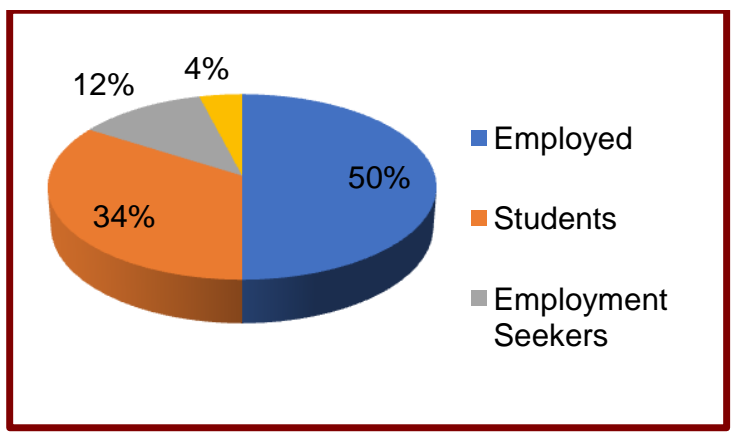


Int J Adv Life Sci Res. Volume 3(4)37-50

Figure 3: Education- wise Distribution of Sample

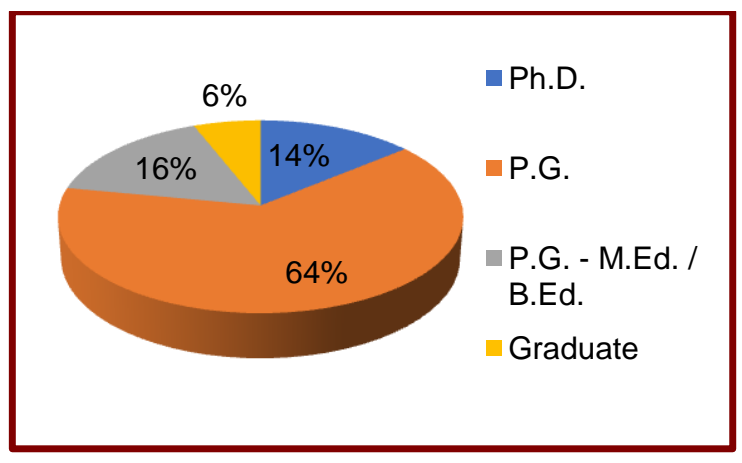

Among 50 participants 25 were employed, 17 were students, 06 were employment seekers as well as 02 were homemakers (Figure 2). The entire sample of this study comprised of 7 Ph.D., 32 P.G., 8 P.G. - M.Ed. /B.Ed. and 3
Graduate participants (Figure 3). Incidental sampling technique was adopted here in this study.

\section{Results and Discussion}

While $18.19 \%$ men opined that plants in their locality were in their own garden, $17.94 \%$ women too had plants in their own garden (Tables 1,2). $9.9 \%$ men had plants in their own terrace/balcony/roof tops and $7.69 \%$ women too had plants in their own terrace/balcony/roof tops. The significant difference was that $23.08 \%$ women opined that plants in their locality were in community parks while only $9.09 \%$ men viewed plants in local community parks.

Table 1. Percentage Analysis of the Male Participants w.r.t. distribution of plants in neighbourhood

\begin{tabular}{|c|c|c|c|c|}
\hline Item & \multicolumn{4}{|c|}{ Options } \\
\hline $\begin{array}{l}\text { Plants found in } \\
\text { your locality were } \\
\text { mostly in - }\end{array}$ & $\begin{array}{l}\text { Own } \\
\text { terrace/balcony/r } \\
\text { oof-top }\end{array}$ & Own garden & $\begin{array}{l}\text { Community } \\
\text { park/playground/ } \\
\text { garden }\end{array}$ & Avenue/roadside \\
\hline $\begin{array}{l}\text { Response (In } \\
\text { terms of \% } \\
\text { analysis) }\end{array}$ & $9.09 \%$ & $18.19 \%$ & $9.09 \%$ & $63.63 \%$ \\
\hline Interpretation & \multicolumn{4}{|c|}{$\begin{array}{l}\text { In the light of the findings it can be said that as per the opinion of the male } \\
\text { participants: } \\
\quad 63.63 \% \text { plants were found near the avenue/roadside. } \\
\quad 9.09 \% \text { plants were in the community park/play ground and in the } \\
\text { garden. } \\
18.19 \% \text { men had plants in their own garden and } \\
9.09 \% \text { men had plants in their own terrace/balcony/roof tops. }\end{array}$} \\
\hline
\end{tabular}

Table 2. Percentage Analysis of the Female Participants w.r.t distribution of plants in neighbourhood

\begin{tabular}{|c|c|c|c|c|}
\hline Item & \multicolumn{4}{|c|}{ Options } \\
\hline $\begin{array}{l}\text { Plants found in } \\
\text { your locality were } \\
\text { mostly in - }\end{array}$ & $\begin{array}{l}\text { Own } \\
\text { terrace/balcony/r } \\
\text { oof-top }\end{array}$ & Own garden & $\begin{array}{l}\text { Community } \\
\text { park/playground/ } \\
\text { garden }\end{array}$ & Avenue/roadside \\
\hline $\begin{array}{l}\text { Response (In } \\
\text { terms of \% } \\
\text { analysis) }\end{array}$ & $7.69 \%$ & $17.94 \%$ & $23.08 \%$ & $51.29 \%$ \\
\hline Interpretation & \multicolumn{4}{|c|}{$\begin{array}{l}\text { According to the opinion of the female participants, it can be said that: } \\
51.29 \% \text { plants were near the avenue/roadside. } \\
23.08 \% \text { plants were in the community park/play ground and in the } \\
\text { garden. } \\
17.94 \% \text { women had plants in their own garden and } \\
7.69 \% \text { women had plants in their own terrace/balcony/roof tops. }\end{array}$} \\
\hline
\end{tabular}

No male claimed trees or plants in their respective locality remained unaffected post Amphan while according to $5.12 \%$ women plants remained unaffected (Tables 3,4). While $54.55 \%$ men said that trees were completely uprooted $51.28 \%$ women reported trees with broken branches. From the survey it is evident that men reported greater green casualties than women in their localities. 
Int J Adv Life Sci Res. Volume 3(4)37-50

Table 3 Percentage Analysis of the Male Participants w.r.t. kind of plant damage

\begin{tabular}{|c|c|c|c|c|}
\hline Items & \multicolumn{4}{|c|}{ Options } \\
\hline $\begin{array}{l}\text { Post Amphan, most } \\
\text { plants in your locality } \\
\text { were }\end{array}$ & Completely uprooted & Broken branches & Bent & Unaffected \\
\hline $\begin{array}{l}\text { Response (In terms of } \\
\% \text { analysis) }\end{array}$ & $54.55 \%$ & $36.36 \%$ & $9.09 \%$ & - \\
\hline Interpretation & \multicolumn{4}{|c|}{$\begin{array}{l}\text { In the light of the findings, according to the opinion of the male } \\
\text { participants it can be said that post Amphan: } \\
. \quad 36.36 \% \text { plants had broken branches. } \\
\quad 54.55 \% \text { plants were completely uprooted and } \\
\quad 9.09 \% \text { plants were bent. }\end{array}$} \\
\hline
\end{tabular}

Table 4 Percentage Analysis of the Female Participants w.r.t. kind of plant damage

\begin{tabular}{|c|c|c|c|c|}
\hline Items & \multicolumn{4}{|c|}{ Options } \\
\hline $\begin{array}{l}\text { Post Amphan, } \\
\text { most plants in } \\
\text { your locality were }\end{array}$ & $\begin{array}{l}\text { Completely } \\
\text { uprooted }\end{array}$ & Broken branches & Bent & Unaffected \\
\hline $\begin{array}{l}\text { Response (In } \\
\text { terms of \% } \\
\text { analysis) }\end{array}$ & $35.89 \%$ & $51.28 \%$ & $7.71 \%$ & $5.12 \%$ \\
\hline Interpretation & \multicolumn{4}{|c|}{ 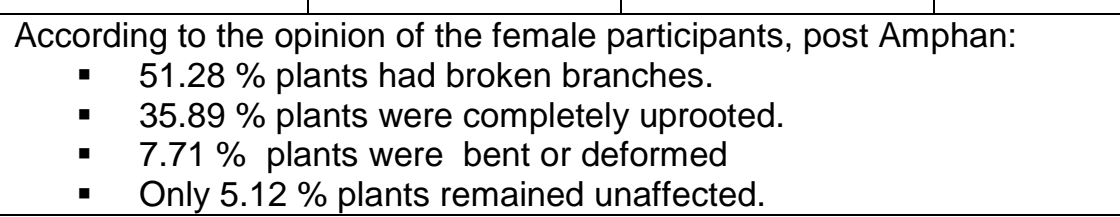 } \\
\hline
\end{tabular}

According to males all local plants affected were the roadside ones whether cemented $(9.09 \%)$ or uncemented $(90.91 \%)$ around the roots while the plants were better protected if they were home-grown or in community parks (Table 5). However the women reported green casualties in all settings ranging from roadside to community parks and private gardens, though the percentage in community parks and gardens were relatively low $-17.94 \%$ and $12.84 \%$ respectively (Table 6 ).

Table 5 Percentage Analysis of the Male Participants w.r.t. location of damaged plants

\begin{tabular}{|l|l|l|l|l|}
\hline \multicolumn{1}{|c|}{ Items } & \multicolumn{3}{|c|}{ Options } \\
\hline $\begin{array}{l}\text { Uprooted or } \\
\text { damaged trees } \\
\text { were } \\
\text { located in }\end{array}$ & $\begin{array}{l}\text { Roadside, } \\
\text { cemently around } \\
\text { roots }\end{array}$ & $\begin{array}{l}\text { Roadside, } \\
\text { uncemented } \\
\text { around roots }\end{array}$ & Community park & Own garden \\
\hline $\begin{array}{l}\text { Response (In } \\
\text { terms of \% } \\
\text { analysis) }\end{array}$ & $9.09 \%$ & $90.91 \%$ & - & - \\
\hline Interpretation & $\begin{array}{l}\text { According to the male participants, the uprooted/damaged trees were mostly } \\
\text { located in: } \\
90.91 \% \text { plants were on the roadside, uncemented around roots. } \\
9.09 \% \text { plants were at the roadside, cemented around roots. }\end{array}$ \\
\hline
\end{tabular}


Table 6 Percentage Analysis of the Female Participants w.r.t. location of damaged plants

\begin{tabular}{|c|c|c|c|c|}
\hline Items & \multicolumn{4}{|c|}{ Options } \\
\hline $\begin{array}{lr}\text { Uprooted } & \text { or } \\
\text { damaged } & \text { trees } \\
\text { were } & \text { mostly } \\
\text { located in } & \end{array}$ & $\begin{array}{l}\text { Roadside, } \\
\text { cemented around } \\
\text { roots }\end{array}$ & $\begin{array}{l}\text { Roadside, } \\
\text { uncemented } \\
\text { around roots }\end{array}$ & Community park & Own garden \\
\hline $\begin{array}{l}\text { Response (In } \\
\text { terms of \% } \\
\text { analysis) }\end{array}$ & $17.94 \%$ & $51.28 \%$ & $17.94 \%$ & $12.84 \%$ \\
\hline Interpretation & \multicolumn{4}{|c|}{$\begin{array}{c}\text { According to the women, uprooted/damaged trees were mostly in: } \\
\text { - } 51.28 \% \text { plants were on the roadside, uncemented around roots. } \\
\text { - } \quad 17.94 \% \text { plants were at the roadside, cemented around roots. } \\
\text { - } \quad 17.94 \% \text { plants were located in the community park and } \\
\text { - } \quad 12.84 \% \text { plants were uprooted from the private gardens }\end{array}$} \\
\hline
\end{tabular}

While overgrown canopy (81.82\%) remained the chief cause of destruction of local trees according to males (Table 7), $64.10 \%$ females also reported this as the main reason. Men also felt that weakly wooded stems with brittle branches and diseased plants were no reasons at all for the destruction caused. However $12.82 \%$ women reported weak stemmed trees as one of the possible reasons for the Amphan havoc (Table 8).

Table 7: Percentage Analysis of the Male Participants w.r.t. reason of plant damage

\begin{tabular}{|l|l|l|l|l|}
\hline \multicolumn{1}{|c|}{ Items } & \multicolumn{3}{c|}{ Options } \\
\hline $\begin{array}{l}\text { The damaged } \\
\text { luprooted trees } \\
\text { were mostly due } \\
\text { to - }\end{array}$ & $\begin{array}{l}\text { Overgrown } \\
\text { canopy }\end{array}$ & $\begin{array}{l}\text { Shallow roots } \\
\text { stems \& brittle } \\
\text { branches }\end{array}$ & $\begin{array}{l}\text { Diseased and } \\
\text { infected }\end{array}$ \\
\hline $\begin{array}{l}\text { Response (In } \\
\text { terms of \% } \\
\text { analysis) }\end{array}$ & $81.82 \%$ & $18.18 \%$ & - & - \\
\hline Interpretation & $\begin{array}{l}\text { As per the opinion of the male participants, the trees were uprooted or } \\
\text { damaged mostly due to the following reasons: } \\
81.82 \% \text { due to overgrown canopy. } \\
18.18 \% \text { due to shallow roots. }\end{array}$ \\
\hline
\end{tabular}

Table 8: Percentage Analysis of the Female Participants w.r.t. reason of plant damage

\begin{tabular}{|l|l|l|l|l|}
\hline \multicolumn{1}{|c|}{ Items } & \multicolumn{3}{c|}{ Options } \\
\hline $\begin{array}{l}\text { The damaged } \\
\text { luprooted trees } \\
\text { were mostly due } \\
\text { to - }\end{array}$ & $\begin{array}{l}\text { Overgrown } \\
\text { canopy }\end{array}$ & Shallow roots & $\begin{array}{l}\text { Weakly wooded } \\
\text { stems \& brittle } \\
\text { branches }\end{array}$ & $\begin{array}{l}\text { Diseased and } \\
\text { infected }\end{array}$ \\
\hline $\begin{array}{l}\text { Response (In } \\
\text { terms of \% } \\
\text { analysis) }\end{array}$ & $64.10 \%$ & $23.08 \%$ & $12.82 \%$ & - \\
\hline Interpretation & $\begin{array}{l}\text { Trees were uprooted or damaged mostly due to the following reasons according } \\
\text { to the opinion of the women: } \\
64.10 \% \text { due to overgrown canopy. } \\
23.08 \% \text { due to shallow roots and } \\
12.82 \% \text { due to weakly wooded stems and brittle branches. }\end{array}$ \\
\hline
\end{tabular}

Majority men (63.63\%) accused lack of space or overcrowding as the chief reason of local tree damage (Table 9) and $64.10 \%$ women also reported the same (Table 10). 
Int J Adv Life Sci Res. Volume 3(4)37-50

Table 9 : Percentage Analysis of the Male Participants w.r.t. existing strategy selection of planting

\begin{tabular}{|c|c|c|c|c|}
\hline Items & \multicolumn{4}{|c|}{ Options } \\
\hline $\begin{array}{l}\text { Reason for tree } \\
\text { damage - }\end{array}$ & $\begin{array}{l}\text { Lack of space, } \\
\text { overcrowded with } \\
\text { wires, cables etc. }\end{array}$ & $\begin{array}{l}\text { Unscientific } \\
\text { pruning/ } \\
\text { no pruning }\end{array}$ & $\begin{array}{l}\text { 'Right place, right } \\
\text { tree' norm not } \\
\text { followed }\end{array}$ & $\begin{array}{l}\text { Wrong species } \\
\text { selection }\end{array}$ \\
\hline $\begin{array}{l}\text { Response (In } \\
\text { terms of \% } \\
\text { analysis) }\end{array}$ & $63.63 \%$ & - & $27.28 \%$ & $9.09 \%$ \\
\hline Interpretation & \multicolumn{4}{|c|}{$\begin{array}{l}\text { In the light of the findings, the reasons for tree damage were: } \\
\text { - } 63.63 \% \text { plants were damaged due to lack of space, overcrowded with } \\
\text { wires, cables etc. } \\
\text { - } 27.28 \% \text { plants were damaged as the 'right place, right tree' norm not } \\
\text { followed and } \\
\text { - } 9.09 \% \text { for wrong species selection. }\end{array}$} \\
\hline
\end{tabular}

Table 10: Percentage Analysis of the Female Participants w.r.t. existing strategy selection of planting

\begin{tabular}{|c|c|c|c|c|}
\hline Items & \multicolumn{4}{|c|}{ Options } \\
\hline $\begin{array}{l}\text { Reason for tree } \\
\text { damage - }\end{array}$ & $\begin{array}{l}\text { Lack of space, } \\
\text { overcrowded with } \\
\text { wires, cables etc. }\end{array}$ & $\begin{array}{l}\text { Unscientific } \\
\text { pruning/ } \\
\text { no pruning }\end{array}$ & $\begin{array}{l}\text { 'Right place, right } \\
\text { tree' norm not } \\
\text { followed }\end{array}$ & $\begin{array}{l}\text { Wrong species } \\
\text { selection }\end{array}$ \\
\hline $\begin{array}{l}\text { Response (In } \\
\text { terms of \% } \\
\text { analysis) }\end{array}$ & $64.10 \%$ & $10.25 \%$ & $17.94 \%$ & $7.71 \%$ \\
\hline Interpretation & \multicolumn{4}{|c|}{$\begin{array}{l}\text { Women stated the following issues as the reasons for tree damage: } \\
\text { - } 64.10 \% \text { plants were damaged due to lack of space, overcrowded with } \\
\text { wires, cables etc. } \\
\text { - } 17.94 \% \text { plants were damaged due to 'right place, right tree' norm not } \\
\text { followed. } \\
\text { - } 10.25 \% \text { due to unscientific pruning/ no pruning and } \\
7.71 \% \text { for wrong species selection. }\end{array}$} \\
\hline
\end{tabular}

Men did not feel that unscientific pruning could be a contributing factor to plant damage but $10.25 \%$ women did. While $100 \%$ men felt that planting the right species along roadsides and avenues would be their only option for future urban greening (Table 11), the women chose several options (Table 12). $74.33 \%$ women voted for the right species plantation along roadsides, $15.38 \%$ opted for community green spaces while $10.27 \%$ wished future urban greening programme to remain unchanged.

Table 11 : Percentage Analysis of the Male Participants w.r.t. future greening programme

\begin{tabular}{|l|l|l|l|l|}
\hline \multicolumn{1}{|c|}{ Items } & \multicolumn{4}{|c|}{ Options } \\
\hline $\begin{array}{l}\text { What would your } \\
\text { future urban } \\
\text { greening plan be } \\
-\end{array}$ & $\begin{array}{l}\text { Trees only in } \\
\text { community green } \\
\text { spaces }\end{array}$ & $\begin{array}{l}\text { Trees in } \\
\text { roadsides, but } \\
\text { right species }\end{array}$ & $\begin{array}{l}\text { Trees are for } \\
\text { personal gardens } \\
\text { only }\end{array}$ & $\begin{array}{l}\text { Unchanged, as it } \\
\text { has been all this } \\
\text { while }\end{array}$ \\
\hline $\begin{array}{l}\text { Response (In } \\
\text { terms of \% } \\
\text { analysis) }\end{array}$ & - & - & - \\
\hline Interpretation & \multicolumn{3}{|c|}{$\begin{array}{l}\text { In the light of findings, people would opt for the right road-side species } \\
\text { approach solely as their future urban greening plan. }\end{array}$} \\
\hline
\end{tabular}


Int J Adv Life Sci Res. Volume 3(4)37-50

Table 12 : Percentage Analysis of the Female Participants w.r.t. future greening programme

\begin{tabular}{|l|l|l|l|l|}
\hline \multicolumn{1}{|c|}{ Items } & \multicolumn{4}{|c|}{ Options } \\
\hline $\begin{array}{l}\text { What would your } \\
\text { future } \begin{array}{c}\text { urban } \\
\text { greening plan be }\end{array}\end{array}$ & $\begin{array}{l}\text { Trees only in } \\
\text { community } \\
\text { green spaces }\end{array}$ & $\begin{array}{l}\text { Trees } \\
\text { roadsides, in but } \\
\text { right species }\end{array}$ & $\begin{array}{l}\text { Trees are for } \\
\text { personal gardens } \\
\text { only }\end{array}$ & $\begin{array}{l}\text { Unchanged, as it } \\
\text { has been all this } \\
\text { while }\end{array}$ \\
\hline $\begin{array}{l}\text { Response (In terms } \\
\text { of \% analysis) }\end{array}$ & $15.38 \%$ & $74.35 \%$ & - & $10.27 \%$ \\
\hline Interpretation & $\begin{array}{l}\text { Women would opt for the following approaches as their future urban greening } \\
\text { plan: }\end{array}$ \\
& $\begin{array}{l}15.38 \% \text { plants would be planted in the community green spaces. } \\
\text { right species approach while } \\
10.27 \% \text { would stick to the old planting pattern. }\end{array}$ \\
\hline
\end{tabular}

From the responses, it is evident that women consider community green spaces as a. Such spaces include parks, urban forests, community gardens in urban areas, primarily covered by vegetation, which are directly (active or passive recreation) or indirectly (positive influence on the urban environment) available for the users (Sen, 2020b). 23.08\% women felt that such spaces held their local green population (Table 2 ) while $9.09 \%$ males voted for them (Table 1). Then again 17.94\% women felt that the local green population ravaged by Amphan belonged to community green spaces (Table 6).

Community green spaces chosen by women is a positive feature, for encouraging such spaces would promote urban greening. This once again points to the women being sensitive to environmental challenges and crises (Sen, 2020c). Most urban green spaces represent original ecosystems providing critical ecosystem services. In fact, urban areas can support endemic native species and others of conservation concern both at regional and global levels (Sen, 2020c). Access to green space is therefore increasingly being recognized as an environmental justice issue as strong links have been established between the human psyche and environment (Biswas and Sen 2020, Sen, 2019).

With respect to profession and academic qualification, the home-makers and graduates made straight choices in case of location of neighbourhood plants. $50 \%$ of the homemakers (all women) reported plants in community greens (Table 13), once again reinforcing the importance of urban green spaces.

Table 13 : Percentage Profession-wise Analysis of the Entire Sample w.r.t. distribution of plants in neighbourhood

\begin{tabular}{|c|c|c|c|c|}
\hline Item & \multicolumn{4}{|c|}{ Options } \\
\hline $\begin{array}{l}\text { Plants found in your } \\
\text { locality were mostly in }\end{array}$ & $\begin{array}{l}\text { Own } \\
\text { terrace/balcony/ } \\
\text { roof-top }\end{array}$ & Own garden & $\begin{array}{l}\text { Community } \\
\text { park/playground/ } \\
\text { garden }\end{array}$ & $\begin{array}{l}\text { Avenue/ } \\
\text { roadside }\end{array}$ \\
\hline \multicolumn{5}{|c|}{ Response (In terms of $\%$ analysis): } \\
\hline Employed & $8 \%$ & $16 \%$ & $20 \%$ & $56 \%$ \\
\hline Student & $11.76 \%$ & $29.41 \%$ & $11.76 \%$ & $47.07 \%$ \\
\hline Seeking Employment & - & $16.66 \%$ & $33.34 \%$ & $50 \%$ \\
\hline Homemaker & - & - & $50 \%$ & $50 \%$ \\
\hline Interpretation & \multicolumn{4}{|c|}{$\begin{array}{l}\text { In the light of the findings it can be said that: } \\
\text { - According to } 56 \% \text { employed, } 47.07 \% \text { students, } 50 \% \text { employment } \\
\text { seekers and } 50 \% \text { homemakers plants were mostly near the } \\
\text { avenue/roadside. } \\
\text { - According to } 20 \% \text { employed, } 11.76 \% \text { students, } 33.34 \% \\
\text { employment seekers and } 50 \% \text { homemakers plants were in the } \\
\text { community park/play ground and garden. } \\
\text { - } 16 \% \text { employed, } 29.41 \% \text { students and } 16.66 \% \text { employment } \\
\text { seekers had plants in their own garden and } \\
\text { - } 8 \% \text { employed and } 11.76 \% \text { students had plants in their own } \\
\text { terrace/balcony/roof tops. }\end{array}$} \\
\hline
\end{tabular}


The remaining 50\% home-makers noticed roadside greenery. The graduates all voted for local roadside greenery (Table 14). Interestingly both Ph.Ds and Graduates did not agree to the fact that local greenery was in their own terrace/balcony/rooftop.
In case of damage to plants both homemakers and those seeking employment chose between completely uprooted plants and plants with broken branches, though in different percentages (Table 15).

Table 14 : Percentage Education -wise Analysis of the Entire Sample w.r.t. distribution of plants in neighbourhood

\begin{tabular}{|c|c|c|c|c|}
\hline Item & \multicolumn{4}{|c|}{ Options } \\
\hline $\begin{array}{l}\text { Plants found in } \\
\text { your locality } \\
\text { were mostly in }\end{array}$ & $\begin{array}{l}\text { Own } \\
\text { terrace/balcony/ } \\
\text { roof-top }\end{array}$ & Own garden & $\begin{array}{l}\text { Community } \\
\text { park/playground/ } \\
\text { garden }\end{array}$ & Avenue/roadside \\
\hline \multicolumn{5}{|c|}{ Response (In terms of \% analysis): } \\
\hline PH.D. & - & $42.85 \%$ & $28.57 \%$ & $28.57 \%$ \\
\hline P.G. & $9.37 \%$ & $15.62 \%$ & $15.62 \%$ & $59.37 \%$ \\
\hline $\begin{array}{l}\text { P.G. M.ED. / } \\
\text { B.ED. }\end{array}$ & $25 \%$ & $12.5 \%$ & $25 \%$ & $37.5 \%$ \\
\hline Graduate & - & - & - & $100 \%$ \\
\hline Interpretation & \multicolumn{4}{|c|}{$\begin{array}{l}\text { In the light of the findings it can be said that: } \\
\text { - According to } 28.57 \% \text { Ph.D. participants, } 59.37 \% \text { P.G. students, } 37.5 \% \\
\text { P.G. M.Ed. / B.Ed. students and } 100 \% \text { graduate, plants were mostly } \\
\text { near the avenue/roadside. } \\
\text { - According to } 28.57 \% \text { Ph.D. participants, } 15.62 \% \text { P.G. students and } \\
25 \% \text { P.G. M.Ed. / B.Ed. students, plants were in the community } \\
\text { park/play ground and garden. } \\
\text { - } 2.85 \% \text { Ph.D. participants, } 15.62 \% \text { P.G. students and } 12.5 \% \text { P.G. } \\
\text { M.Ed. / B.Ed. students had plants in their own garden and } \\
\text { - } 9.37 \% \text { P.G. students and } 25 \% \text { P.G. M.Ed. / B.Ed. students had plants } \\
\text { in their own terrace/balcony/roof tops. }\end{array}$} \\
\hline
\end{tabular}

Table 15 Percentage Profession-wise Analysis of the Entire Sample w.r.t. kind of plant damage

\begin{tabular}{|c|c|c|c|c|}
\hline Items & \multicolumn{4}{|c|}{ Options } \\
\hline $\begin{array}{l}\text { Post Amphan, } \\
\text { most plants in } \\
\text { your locality were }\end{array}$ & $\begin{array}{l}\text { Completely } \\
\text { uprooted }\end{array}$ & Broken branches & Bent & Unaffected \\
\hline \multicolumn{5}{|c|}{ Response (In terms of \% analysis): } \\
\hline Employed & $40 \%$ & $44 \%$ & $12 \%$ & $4 \%$ \\
\hline Student & $41.17 \%$ & $47.05 \%$ & $5.89 \%$ & $5.89 \%$ \\
\hline $\begin{array}{l}\text { Seeking } \\
\text { Employment }\end{array}$ & $24.98 \%$ & $74.98 \%$ & - & - \\
\hline Homemaker & $50 \%$ & $50 \%$ & - & - \\
\hline Interpretation & \multicolumn{4}{|c|}{$\begin{array}{l}\text { In the light of the findings it can be said that post Amphan: } \\
\text { - According to } 44 \% \text { employed, } 47.05 \% \text { students, } 74.98 \% \text { employment } \\
\text { seekers and } 50 \% \text { homemakers plants had broken branches. } \\
\text { - According to } 40 \% \text { employed, } 41.17 \% \text { students, } 24.98 \% \text { employment } \\
\text { seekers and } 50 \% \text { homemakers plants were completely uprooted. } \\
\text { - According to } 12 \% \text { employed and } 5.89 \% \text { students plants were } \\
\text { bent/deformed and } \\
\text { - According to } 4 \% \text { employed and } 5.89 \% \text { students only plants remained } \\
\text { unaffected. }\end{array}$} \\
\hline
\end{tabular}


Int J Adv Life Sci Res. Volume 3(4)37-50

Nearly $75 \%$ of those seeking employment reported trees with broken branches postAmphan. Both the graduate and Ph.D groups felt that all plants were affected in some way or the other and no plant remain unaffected after Amphan (Table 16).

Table 17 reveals that $50 \%$ home-makers report damaged greenery from community greens thus showing the relevance and importance of such spaces in urban greening (Sen, 2020d). Both the employed and the home-makers agreed that plants in private gardens remained unaffected post Amphan possibly because of the caution exercised by the owners. The Graduates also agreed on this point (Table 18) along with the PG trained teachers.

Table 16 Percentage Education -wise Analysis of the Entire Sample w.r.t. kind of plant damage

\begin{tabular}{|c|c|c|c|c|}
\hline Items & \multicolumn{4}{|c|}{ Options } \\
\hline $\begin{array}{l}\text { Post Amphan, most } \\
\text { plants in your } \\
\text { locality were }\end{array}$ & $\begin{array}{l}\text { Completely } \\
\text { uprooted }\end{array}$ & $\begin{array}{l}\text { Broken } \\
\text { branches }\end{array}$ & Bent & Unaffected \\
\hline \multicolumn{5}{|c|}{ Response (In terms of \% analysis): } \\
\hline PH.D. & $28.57 \%$ & $57.14 \%$ & $14.28 \%$ & - \\
\hline P.G. & $43.75 \%$ & $43.75 \%$ & $9.37 \%$ & $3.12 \%$ \\
\hline P.G. M.ED. / B.ED. & $25 \%$ & $62.5 \%$ & - & $12.5 \%$ \\
\hline Graduate & $66.66 \%$ & $33.33 \%$ & - & - \\
\hline Interpretation & \multicolumn{4}{|c|}{$\begin{array}{l}\text { Post Amphan: } \\
\text { According to } 57.14 \% \text { Ph.D. participants, } 43.75 \% \text { P.G. students, } \\
\text { 62.5\% P.G. M.Ed. / B.Ed. students and } 33.33 \% \text { graduate, plants } \\
\text { were with broken branches. } \\
\text { - According to } 28.57 \% \text { Ph.D. participants, } 43.75 \% \text { P.G. students, } \\
\text { 25\% P.G. M.Ed. / B.Ed. students and } 66.66 \% \text { graduate, plants were } \\
\text { completely uprooted. } \\
\text { According to } 14.28 \% \text { Ph.D. participants and 9.37\% P.G. students, } \\
\text { plants were bent/ deformed } \\
\text { Only according to 3.12\% P.G. students, } 12.5 \% \text { P.G. M.Ed. / B.Ed. } \\
\text { students, plants remained unaffected. }\end{array}$} \\
\hline
\end{tabular}

Table 17 Percentage Profession-wise Analysis of the Entire Sample w.r.t. location of damaged plants

\begin{tabular}{|c|c|c|c|c|}
\hline Items & \multicolumn{4}{|c|}{ Options } \\
\hline $\begin{array}{lr}\text { Uprooted } & \text { or } \\
\text { damaged } & \text { trees } \\
\text { were } & \text { mostly } \\
\text { located in } & \end{array}$ & $\begin{array}{l}\text { Roadside, } \\
\text { cemented around } \\
\text { roots }\end{array}$ & $\begin{array}{l}\text { Roadside, } \\
\text { uncemented } \\
\text { around roots }\end{array}$ & Community park & Own garden \\
\hline \multicolumn{5}{|c|}{ Response (In terms of \% analysis): } \\
\hline Employed & $20 \%$ & $68 \%$ & $12 \%$ & - \\
\hline Student & $17.64 \%$ & $47.05 \%$ & $11.76 \%$ & $23.55 \%$ \\
\hline $\begin{array}{l}\text { Seeking } \\
\text { Employment }\end{array}$ & $16.66 \%$ & $33.33 \%$ & $33.33 \%$ & $16.68 \%$ \\
\hline Homemaker & - & $50 \%$ & $50 \%$ & - \\
\hline Interpretation & \multicolumn{4}{|c|}{$\begin{array}{l}\text { In the light of the findings it can be said that uprooted/damaged trees were } \\
\text { mostly located in: } \\
\text { According to } 68 \% \text { employed, } 47.05 \% \text { students, } 33.33 \% \text { employment } \\
\text { seekers and } 50 \% \text { homemakers plants were on the roadside, } \\
\text { uncemented around roots. } \\
\text { According to } 20 \% \text { employed, } 17.64 \% \text { students and } 16.66 \% \\
\text { employment seekers plants were at the roadside, cemented around } \\
\text { roots. } \\
\text { According to } 12 \% \text { employed, } 11.76 \% \text { students, } 33.33 \% \text { employment } \\
\text { seekers and } 50 \% \text { homemakers plants were located in the community } \\
\text { park and } \\
\text { According to } 23.55 \% \text { students and } 16.68 \% \text { employment seekers plants } \\
\text { were uprooted from the private garden of the people. }\end{array}$} \\
\hline
\end{tabular}


Int J Adv Life Sci Res. Volume 3(4)37-50

Table 18 Percentage Education -wise Analysis of the Entire Sample w.r.t. location of damaged plants

\begin{tabular}{|c|c|c|c|c|}
\hline Items & \multicolumn{4}{|c|}{ Options } \\
\hline 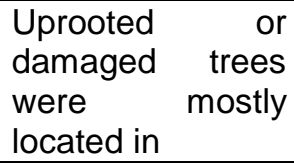 & $\begin{array}{l}\text { Roadside, } \\
\text { cemented around } \\
\text { roots }\end{array}$ & $\begin{array}{l}\text { Roadside, } \\
\text { uncemented } \\
\text { around roots }\end{array}$ & Community park & Own garden \\
\hline \multicolumn{5}{|c|}{ Response (In terms of \% analysis): } \\
\hline PH.D. & $14.28 \%$ & $57.14 \%$ & $14.28 \%$ & $14.28 \%$ \\
\hline P.G. & $12.5 \%$ & $62.5 \%$ & $12.5 \%$ & $12.5 \%$ \\
\hline $\begin{array}{l}\text { P.G. M.ED. / } \\
\text { B.ED. }\end{array}$ & $25 \%$ & $50 \%$ & $25 \%$ & \\
\hline Graduate & $66.66 \%$ & $33.33 \%$ & - & - \\
\hline Interpretation & \multicolumn{4}{|c|}{$\begin{array}{l}\text { In the light of the findings it can be said that uprooted/damaged trees were } \\
\text { mostly located in: } \\
\text { According to } 14.28 \% \text { Ph.D. participants, } 12.5 \% \text { P.G. students, } 25 \% \\
\text { P.G. M.Ed. /B.Ed. and } 66.66 \% \text { graduate, plants were on the roadside, } \\
\text { cemented around roots. } \\
\text { - According to } 57.14 \% \text { Ph.D. participants, } 62.5 \% \text { P.G. students, } 50 \% \\
\text { P.G. M.Ed. /B.Ed. students and } 33.33 \% \text { graduate, plants were at the } \\
\text { roadside, uncemented around roots. } \\
\text { According to } 14.28 \% \text { Ph.D. participants, } 12.5 \% \text { P.G. students and } 25 \% \\
\text { P.G. M.Ed. /B.Ed. students, plants were located in the community park } \\
\text { and } \\
\text { According to } 14.28 \% \text { P.G. students and } 12.5 \% \text { P.G. M.Ed. /B.Ed. } \\
\text { students, plants were uprooted from private gardens. }\end{array}$} \\
\hline
\end{tabular}

No segment (either profession or qualification wise) believed that the massive green destruction was due to diseased or infected plants (Tables 19, 20). All three groups employed, students and those seeking employment in higher percentages accounted overgrown canopy as the cause of damage.
While the doctorates, $P G$ s and $P G$ trained teachers also agreed in higher percentages as overgrown canopy being chief cause of destruction, $66.66 \%$ graduates believed shallow roots to be the main reason behind destruction.

Table 19: Percentage Profession-wise Analysis of the Entire Sample w.r.t. reason of plant damage

\begin{tabular}{|c|c|c|c|c|}
\hline Items & \multicolumn{4}{|c|}{ Options } \\
\hline $\begin{array}{l}\text { The } \\
\text { damaged } \\
\text { /uprooted } \\
\text { trees were } \\
\text { mostly due to } \\
\text { - }\end{array}$ & Overgrown canopy & $\begin{array}{l}\text { Shallow } \\
\text { roots }\end{array}$ & $\begin{array}{l}\text { Weakly wooded stems \& brittle } \\
\text { branches }\end{array}$ & $\begin{array}{l}\text { Diseased } \\
\text { and infected }\end{array}$ \\
\hline \multicolumn{5}{|c|}{ Response (In terms of \% analysis): } \\
\hline Employed & $72 \%$ & $24 \%$ & $4 \%$ & - \\
\hline Student & $64.71 \%$ & $17.64 \%$ & $17.65 \%$ & - \\
\hline $\begin{array}{l}\text { Seeking } \\
\text { Employment }\end{array}$ & $66.68 \%$ & $16.66 \%$ & $16.66 \%$ & - \\
\hline Homemaker & $50 \%$ & $50 \%$ & - & - \\
\hline Interpretation & \multicolumn{4}{|c|}{$\begin{array}{l}\text { Trees were uprooted or damaged mostly due to the following reasons: } \\
\text { - According to } 72 \% \text { employed, } 64.71 \% \text { students, } 66.68 \% \text { employment } \\
\text { seekers and } 50 \% \text { homemakers due to overgrown canopy. } \\
\text { - According to } 24 \% \text { employed, } 17.64 \% \text { students, } 16.66 \% \text { employment } \\
\text { seekers and } 50 \% \text { homemakers due to shallow roots and } \\
\text { - According to } 4 \% \text { employed, } 17.65 \% \text { students and } 16.66 \% \text { employment } \\
\text { seekers due to weakly wooded stems and brittle branches. }\end{array}$} \\
\hline
\end{tabular}


Table 20: Percentage Education -wise Analysis of the Entire Sample w.r.t. reason of plant damage

\begin{tabular}{|c|c|c|c|c|}
\hline Items & \multicolumn{4}{|c|}{ Options } \\
\hline $\begin{array}{l}\text { The damaged } \\
\text { /uprooted trees } \\
\text { were mostly due } \\
\text { to }\end{array}$ & $\begin{array}{l}\text { Overgrown } \\
\text { canopy }\end{array}$ & Shallow roots & $\begin{array}{l}\text { Weakly wooded } \\
\text { stems \& brittle } \\
\text { branches }\end{array}$ & $\begin{array}{l}\text { Diseased and } \\
\text { infected }\end{array}$ \\
\hline \multicolumn{5}{|c|}{ Response (In terms of \% analysis): } \\
\hline PH.D. & $71.42 \%$ & $28.57 \%$ & - & - \\
\hline P.G. & $71.87 \%$ & $15.62 \%$ & $12.5 \%$ & - \\
\hline $\begin{array}{l}\text { P.G. M.ED. / } \\
\text { B.ED. }\end{array}$ & $62.5 \%$ & $25 \%$ & $12.5 \%$ & - \\
\hline Graduate & $33.33 \%$ & $66.66 \%$ & - & - \\
\hline Interpretation & \multicolumn{4}{|c|}{$\begin{array}{l}\text { In the light of the findings it can be said that the trees were uprooted or } \\
\text { damaged mostly due to: } \\
\text { According to } 71.42 \% \text { Ph.D. participants, } 71.87 \% \text { P.G. students, } 62.5 \% \\
\text { P.G. M.Ed. / B.Ed. students and } 33.33 \% \text { graduates, due to overgrown } \\
\text { canopy. } \\
\text { - According to } 28.57 \% \text { Ph.D. participants, } 15.62 \% \text { P.G. students, } 25 \% \\
\text { P.G. M.Ed. / B.Ed. students and } 66.66 \% \text { graduates, due to shallow } \\
\text { roots and } \\
\text { - According to } 12.5 \% \text { P.G. students and 12.5\% P.G. M.Ed. / B.Ed. } \\
\text { students due to weakly wooded stems and brittle branches. }\end{array}$} \\
\hline
\end{tabular}

Trying to ascertain the cause of damage all three groups of employed, students and those seeking employment pointed to lack of space or overcrowding (Table 21) in greater percentages. Students and home-makers did not account unscientific pruning for the damages to green life. On the other hand Ph.Ds and graduates alike did not believe that unscientific or no pruning could result in plant damage (Table 22). Wrong species selection did not result in the large scale havoc caused by Amphan, reported the Ph.Ds, PG trained teachers and graduates. While $75 \%$ PG trained teachers blamed the pruning practices, the other three groups pointed to overcrowding as the principal reason behind such massive damage. Haq et al. (2012) observed that most trees damaged by the cyclone Sidr in November 2007 had been planted in a disorderly manner and were allowed to grow without proper pruning.

Table 21 Percentage Profession-wise Analysis of the Entire Sample w.r.t. existing strategy selection of planting

\begin{tabular}{|l|l|l|l|l|}
\hline \multicolumn{1}{|c|}{ Items } & \multicolumn{3}{|c|}{ Options } \\
\hline $\begin{array}{l}\text { Reason for tree } \\
\text { damage - }\end{array}$ & $\begin{array}{l}\text { Lack of space, } \\
\text { overcrowded with } \\
\text { wires, cables etc. }\end{array}$ & $\begin{array}{l}\text { Unscientific } \\
\text { pruning/ } \\
\text { no pruning }\end{array}$ & $\begin{array}{l}\text { 'Right place, right } \\
\text { tree' norm not } \\
\text { followed }\end{array}$ & $\begin{array}{l}\text { Wrong species } \\
\text { selection }\end{array}$ \\
\hline Response (In terms of \% analysis): & $24 \%$ & $4 \%$ \\
\hline Employed & $64 \%$ & $8 \%$ & $17.64 \%$ & $11.77 \%$ \\
\hline Student & $70.59 \%$ & - & $16.66 \%$ & $16.66 \%$ \\
\hline $\begin{array}{l}\text { Seeking } \\
\text { Employment }\end{array}$ & $50.02 \%$ & $16.66 \%$ & $50 \%$ \\
\hline Homemaker & $50 \% \quad$ light of the findings reasons for tree damage were: \\
\hline Interpretation & $\begin{array}{l}\text { According to 64\% employed, 70.59\% students, 50.02\% employment } \\
\text { seekers and 50\% homemakers plants were damaged due to lack of }\end{array}$ \\
& $\begin{array}{l}\text { space, overcrowded with wires, cables etc. } \\
\text { As per 24\% employed, 17.64\% students and 16.66\% employment } \\
\text { seekers plants were damaged due to 'right place, right tree' norm not } \\
\text { followed. } \\
\text { According to 8\% employed and 16.66\% employment seekers due to }\end{array}$ \\
\hline
\end{tabular}


Int J Adv Life Sci Res. Volume 3(4)37-50

\begin{tabular}{|l|l|}
\hline & $\begin{array}{l}\text { unscientific pruning/ no pruning at all and } \\
\text { According to } 4 \% \text { employed, } 11.77 \% \text { students, } 16.66 \% \text { employment } \\
\text { seekers and } 50 \% \text { homemakers for wrong species selection. }\end{array}$ \\
\hline
\end{tabular}

Table 22 Percentage Education - wise Analysis of the Entire Sample w.r.t. existing strategy selection of planting

\begin{tabular}{|c|c|c|c|c|}
\hline Items & \multicolumn{4}{|c|}{ Options } \\
\hline $\begin{array}{l}\text { Reason for tree } \\
\text { damage - }\end{array}$ & $\begin{array}{l}\text { Lack of space, } \\
\text { overcrowded with } \\
\text { wires, cables etc. }\end{array}$ & $\begin{array}{l}\text { Unscientific } \\
\text { pruning/ } \\
\text { no pruning }\end{array}$ & $\begin{array}{l}\text { 'Right place, right } \\
\text { tree' norm not } \\
\text { followed }\end{array}$ & $\begin{array}{l}\text { Wrong species } \\
\text { selection }\end{array}$ \\
\hline \multicolumn{5}{|c|}{ Response (In terms of \% analysis): } \\
\hline PH.D. & $57.14 \%$ & - & $42.25 \%$ & - \\
\hline P.G. & $68.75 \%$ & $3.13 \%$ & $15.63 \%$ & $12.5 \%$ \\
\hline $\begin{array}{l}\text { P.G. M.ED. / } \\
\text { B.ED. }\end{array}$ & $12.5 \%$ & $75 \%$ & $12.5 \%$ & - \\
\hline Graduate & $100 \%$ & - & - & - \\
\hline Interpretation & \multicolumn{4}{|c|}{$\begin{array}{l}\text { In the light of the findings reasons for tree damage were: } \\
\text { According to } 57.14 \% \text { Ph.D. participants, } 68.75 \% \text { P.G. students, } 12.5 \% \\
\text { P.G. -M.Ed. / B.Ed. students and } 100 \% \text { graduate, plants were } \\
\text { damaged due to lack of space, overcrowded with wires, cables etc. } \\
\text { - As per } 42.25 \% \text { Ph.D. participants, } 15.63 \% \text { P.G. and12.5\% P.G. - } \\
\text { M.Ed. / B.Ed. students, plants were damaged due to 'right place, right } \\
\text { tree' norm not followed. } \\
\text { According to } 3.13 \% \text { P.G. students and75\% P.G. -M.Ed. / B.Ed. } \\
\text { students } \\
\text { due to unscientific pruning/ no pruning at all and } \\
\text { - According to } 12.5 \% \text { P.G. students only for wrong species selection. }\end{array}$} \\
\hline
\end{tabular}

As the future greening programme most opted for the right species to be planted on the roadsides (Tables 23,24$)$. The home makers and graduates unanimously found this the best option for future planning. This also conclusively proves that urban green planning is to be executed with utmost care, background knowledge and firsthand experience. The principles of 'Right place, Right tree,' 'Safety First', landscape architecture besides plant traits, characters and requirements must serve as strong guiding factors (Sen, 2020d). Characteristics of cyclone-resistant trees have to be kept in mind before selecting species for congested areas in cities (Arzoo and Pradhan, 2020).

Table 23: Percentage Profession-wise Analysis of the Entire Sample w.r.t. future greening programme

\begin{tabular}{|c|c|c|c|c|}
\hline Items & \multicolumn{4}{|c|}{ Options } \\
\hline $\begin{array}{l}\text { What would your } \\
\text { future urban } \\
\text { greening plan be }\end{array}$ & $\begin{array}{l}\text { Trees only in } \\
\text { community green } \\
\text { spaces }\end{array}$ & $\begin{array}{lr}\text { Trees } & \text { in } \\
\text { roadsides, } & \text { but } \\
\text { right species } & \end{array}$ & $\begin{array}{l}\text { Trees are for } \\
\text { personal gardens } \\
\text { only }\end{array}$ & $\begin{array}{l}\text { Unchanged, as it } \\
\text { has been all this } \\
\text { while }\end{array}$ \\
\hline \multicolumn{5}{|c|}{ Response (In terms of \% analysis): } \\
\hline Employed & $8 \%$ & $88 \%$ & - & $4 \%$ \\
\hline Student & $11.77 \%$ & $70.58 \%$ & - & $17.65 \%$ \\
\hline $\begin{array}{l}\text { Seeking } \\
\text { Employment }\end{array}$ & $16.66 \%$ & $66.68 \%$ & $16.66 \%$ & - \\
\hline Homemaker & - & $100 \%$ & - & - \\
\hline Interpretation & \multicolumn{4}{|c|}{$\begin{array}{l}\text { In the light of the findings it can be said that people would opt for the following } \\
\text { approaches for their future urban greening plan : } \\
\text { - According to } 88 \% \text { employed, } 70.58 \% \text { students and } 66.68 \% \text { employment } \\
\text { seekers and } 100 \% \text { homemakers plants/trees would be planted in } \\
\text { roadsides but right species. } \\
\text { - According to } 8 \% \text { employed, } 11.77 \% \text { students and } 16.66 \% \text { employment } \\
\text { seekers trees would be planted in community green spaces and } \\
\text { - Only } 4 \% \text { employed and } 17.65 \% \text { students would stick to the old planting } \\
\text { pattern. }\end{array}$} \\
\hline
\end{tabular}


Int J Adv Life Sci Res. Volume 3(4)37-50

Table 24 : Percentage Education -wise Analysis of the Entire Sample w.r.t. future greening programme

\begin{tabular}{|c|c|c|c|c|}
\hline Items & \multicolumn{4}{|c|}{ Options } \\
\hline $\begin{array}{ll}\text { What } & \text { would } \\
\text { your future } \\
\text { urban greening } \\
\text { plan be- }\end{array}$ & $\begin{array}{l}\text { Trees only in } \\
\text { community green } \\
\text { spaces }\end{array}$ & $\begin{array}{lr}\text { Trees } & \text { in } \\
\text { roadsides, } & \text { but } \\
\text { right species } & \end{array}$ & $\begin{array}{l}\text { Trees are for } \\
\text { personal gardens } \\
\text { only }\end{array}$ & $\begin{array}{l}\text { Unchanged, as it } \\
\text { has been all this } \\
\text { while }\end{array}$ \\
\hline \multicolumn{5}{|c|}{ Response (In terms of $\%$ analysis): } \\
\hline PH.D. & $14.29 \%$ & $85.71 \%$ & - & - \\
\hline P.G. & $12.5 \%$ & $75.5 \%$ & - & $12.5 \%$ \\
\hline $\begin{array}{l}\text { P.G. M.ED. / } \\
\text { B.ED. }\end{array}$ & $25 \%$ & $75 \%$ & - & - \\
\hline Graduate & - & $100 \%$ & - & - \\
\hline Interpretation & \multicolumn{4}{|c|}{$\begin{array}{l}\text { In the light of the findings it can be said that people would opt for the following } \\
\text { approaches for their future urban greening plan : } \\
\text { According to } 85.71 \% \text { Ph.D. participants, } 75.5 \% \text { P.G. students, } 66.68 \% \\
\text { P.G. - M.Ed. / B.Ed. students and } 100 \% \text { graduates, right species of } \\
\text { plants/trees should be planted along roadsides. } \\
\text { According to } 14.29 \% \text { Ph.D. participants, } 12.5 \% \text { P.G. students and } 25 \% \\
\text { P.G. - M.Ed. / B.Ed. students, trees should be planted in community } \\
\text { green spaces and } \\
\text { Only } 12.5 \% \text { P.G. students would stick to the old planting pattern. }\end{array}$} \\
\hline
\end{tabular}

It is also interesting to note that in all aspects home-makers restricted themselves to not more than two options and in some cases were even unanimous, much like the graduates.

After conducting the survey it is strongly felt that apart from residents, students from local educational institutions may be invited and encouraged to play active roles in the maintenance of the green space. The academia has a great role to play and with all schools and colleges making the study of Environmental Science/Studies obligatory the students would be eager to participate (Sen 2014a, 2018a). Nearly all academic institutions have eco/green clubs, NSS, environment cell and social outreach programs which can be put to best use. Autonomous community efforts go a long way in environment management (Sen, 2014b, 2016). Community based conservation programs with the participatory approach and performancebased incentive programs encourage

\section{References}

Arzoo, A. and Pradhan, S. (2020). A Review On Cyclone Resistant Plants Found In Cyclone Prone Odisha, India, International Journal of Scientific \& Technology Research 9(4): 488-491.

Biswas, R and Sen, S. (2020). Urban EcoPsychological Attitude during COVID 19 competition and result in better output (Sen 2015, 2018b).

\section{Conclusion :}

We would have to take lessons from such surveys for future urban re-greening. A city's resilience to natural disasters can be comprehended by its ability to adapt to changes, its capacity to help mitigate their impacts and most importantly the positive participation of the concerned community.

\section{Acknowledgments:}

The authors are thankful to the authorities of Institute of Education (P.G.) for Women, Chandernagore and Asutosh College, Kolkata, India for granting necessary permission to carry out this work.

\section{Conflicts of Interest:}

The authors declare that the research was conducted in the absence of any commercial or economic associations that could be construed as a potential conflict of interest.

'Lockdown': A Survey, International Journal of Creative Research Thoughts 8(7): 3017-3037.

Haq, Z. et al. (2012). Damage and management of cyclone Sidr-affected homestead tree plantations: A case study from Patuakhali, Bangladesh, Nat 
Int J Adv Life Sci Res. Volume 3(4)37-50

Hazards 64:1305-1322 . DOI 10.1007/s11069-0120299-x.

Sen, S. (2020a). Kolkata Greens, Post 'Amphan', International Journal of Research and Analytical Reviews, 7(2):368-371.

http://doi.one/10.1729/Journal.23702

Sen, S. (2020b). The City Greens: Ushering Sustainable Urbanization, International Journal of Creative Research Thoughts, 8(4):2689-2696. http://doi.one/10.1729/Journal.23523

Sen, S. (2020c). Gender, Environment and Sustainability: The Journey from 'Silent Spring' to 'Staying Alive,' Int J Adv Life Sci Res. 3(2): 11- 22. https://doi.org/:10.31632/ijalsr.2020v03i02.002

Sen, S. (2020d). 'Green'-Ing Kolkata: Creating A Sustainable City - An Overview, International Journal of Research and Analytical Reviews, 7(2): 743-752. http://doi.one/10.1729/Journal.23607

Sen, S. (2019). "Sustainability Education: Integrating Psychology with Environment" in Cognizance the New Vistas of Education and Psychology, Volume 1 pp. 11-22.

Sen, S. (2018a). Education for Sustainability: Bridging Academia \& Society, Education, Research and Analysis, 5(1.3): 70-73.
Sen, S. (2018b). "Many Faces of Resource Management: Blueprint for Sustainable Conservation" in Muses Volume 1 (ed. Dr. S.Sen), pp. 123-135. Available at: http://www.harvestjournal.net/wpcontent/uploads/2018/02/Muses-Volume-1-2018.pdf Sen, S. (2016). Towards Sustainable Biodiversity Conservation: Community - Based Management Approaches, The Beats of Natural Sciences, 3(2):16.

Sen, S. (2015). "Sustainable Resource Management: Myth or Reality" in Biodiversity, Conservation and Sustainable Development: Issues And Approaches, Volume-1 (Ed. Dr. P. Jha), New Academic Publishers, New Delhi-110002, pp.1-18.

Sen, S. (2014a). Strive to Sustainability: Education for Sustainable Development, Magis -Xaverian Journal of Education, 3:1-7.

Sen S. (2014b). Changing Perspectives In Biodiversity Management: The Indian Context, Journal of Environment and Sociobiology, 11(1), 117-122. 